Selcuk Journal of Agriculture and Food Sciences

http://sjafs.selcuk.edu.tr/sjafs/index

Research Article
SJAFS

(2019) 33 (2), $62-66$

e-ISSN: $2458-8377$

DOI:10.15316/SJAFS.2019.157

\title{
The Effect of Microbial Fertilizer Applications on Grape Yield, Quality and Mineral Nutrition of Some Early Table Grape Varieties
}

\author{
Serpil TANGOLAR ${ }^{1}$, Semih TANGOLAR ${ }^{1}$, Ayfer ALKAN TORUN ${ }^{2}$, Güzin TARIM ${ }^{3}$, Melike ADA $^{1}$, Oğuzhan \\ AYDIN $^{2}$, Sevda KAÇMAZ ${ }^{1}$ \\ ${ }^{1}$ Çukurova University, Faculty of Agriculture, Department of Horticulture, Adana, Turkey \\ ${ }^{2}$ Çukurova University, Faculty of Agriculture, Department of Soil Science and Plant Nutrition, Adana, Turkey \\ ${ }^{3}$ Alata Horticultural Research Institute, Mersin, Turkey
}

\begin{tabular}{l}
\hline ARTICLE INFO \\
\hline Article history: \\
Received : 25.03.2019 \\
Accepted : 29.04 .2019 \\
\hline Edited by: \\
Ali SABIR; Selçuk University, Turkey \\
Reviewed by: \\
Rüstem CANGİ; Tokat Gaziosmanpaşa \\
University, Turkey \\
Ilknur KORKUTAL; Tekirdağ Namık \\
Kemal University,Turkey \\
\hline
\end{tabular}

Keywords:

Grapevine

Grape

Microbial fertilizer

Macro and micro mineral element

Chlorella vulgaris

\begin{abstract}
In this study, a commercial microbial fertilizer (Bio fertilizer) containing $3.5 \times 10^{7}$ cells $/ \mathrm{mL}$ of Chlorella vulgaris algae with a $\mathrm{pH}$ ranging from 3.5 to 5.5 was used. Four applications of microbial fertilizer; 1) control (no fertilizer), 2) leaf treatment, 3) soil treatment, 4) soil plus leaf treatment were performed in the experiment. The effects of the treatments on grape yield and cluster, berry and juice characteristics of 4 years old Trakya ilkeren, Yalova incisi and Prima grape varieties were investigated. In addition, the effects of these applications on macro and micro element contents of leaf samples were examined during the veraison. Microbial fertilizer application was done 5 times starting with the shoot length of $20 \mathrm{~cm}$ and including the veraison time. The highest yield $(6076$ $\mathrm{g} /$ vine, $3038 \mathrm{~kg} / \mathrm{da})$, bunch weight $(300.1 \mathrm{~g})$ and 100 berry weight $(622.6 \mathrm{~g})$ as well as other berry characteristics and maturity index (60.21) values were obtained from the Yalova incisi variety. It has been determined that the most suitable fertilizer application was soil+leaf application with the highest yield (4059 g/vine, $2030 \mathrm{~kg} / \mathrm{da}$ ) and bunch weight $(249.7 \mathrm{~g}$ ). It has been observed that soil application caused earlier maturation of the grapes. The content of nutrients in the leaf samples was different in terms of varieties except nitrogen and manganese. The highest $\mathrm{K}$ content was found in Trakya ilkeren; while highest $\mathrm{Ca}, \mathrm{Mg}$ and $\mathrm{Fe}$ were found in Yalova incisi and highest $\mathrm{P}, \mathrm{Fe}$ and $\mathrm{Zn}$ were in the Prima variety. There were no significant differences in leaf N, P, $\mathrm{Mn}$ and $\mathrm{Zn}$ contents between fertilizer applications. For the other elements, the highest values were obtained from leaf application followed by soil plus leaf applications.
\end{abstract}

\section{Introduction}

For feeding the growing world population, researchers have been struggling to increase the amount of crops that can be obtained from the unit area by using the concentrated drugs and fertilizers. This effort brought along some adverse effects on human health. In order to influence this negative outcome, researchers have accelerated their efforts in organic farming since 1980s. In organic farming, increasing the soil fertility and plant nutrition are the most effective factors on yield and quality. It is seen that in this cultivation form, there is a very limited amount of organic fertilizer resources to be used for increasing the soil fertility or plant nutrition. For this reason, efforts are being made to increase the amount of organic fertilizers used in the plant nutrition.

\footnotetext{
* Corresponding author email: stangolar@cu.edu.tr
}

The most important tool used to improve soil fertility and crop yield is fertilization. Mineral fertilizers and other chemicals not only have negative effects on the environment, but also affect the fruit content, causing the harmful residues in the fruit (Mostafa, 2008). Biofertilizers are very safe for people, animals and the environment. They have capacity to reduce soil pollution, salinity and fertilizing costs by reducing the use of mineral fertilizers.

Recently, the efforts of researchers on the possibility of using some microalgae species in organic farming are remarkable. As a related preparation, Chlorella vulgaris of microalgae species has been widely commercialized and tested in different plant groups (Özdemir et al., 2016). It is thought that $C$. vulgaris could be used as a nitrogen source in agriculture instead of traditional fertilizers. However, it has been determined that the number of studies conducted on the 
use of microalgae as bio-fertilizer in the world and in Turkey is low.

C. vulgaris extract contains $50-60 \%$ protein and is the one of the most efficient chlorophyll resource in the nature. This microorganism contains growth regulators, polyamines, vitamins as well as nitrogen and elements including phosphorus, potassium, calcium,sulfur, zinc, iron, manganese, copper, molybdenum and cobalt. In gardens, it is used to increase vegetative growth, yield and fruit quality (Abd El Moniem and Abd Allah, 2008).

In recent years, the use of organic fertilizers instead of mineral fertilizers has become attractive due to the high cost of mineral fertilizers and harmful effects. Organic fertilizers increase the activity and number of microorganisms in the soil, improve the water holding capacity of the soil and soil structure (Abd El-Moniem et al., 2008, Sönmez and Y1lmaz, 2017, Gougoulias et al., 2018). Bio-fertilizers that are thought to be used instead of chemical fertilizers, consist of organisms that enrich the nutrient capacity of soil and plants. The main sources of bio fertilizers are bacteria, fungi and cyanobacterias (Bileva, 2013, Uysal ve ark., 2015). In this study, it was aimed to determine the effect of $C$. vulgaris, which is rich in protein content in green algae group, on the yield and quality of grapes as microbial fertilizer.

\section{Materials and Methods}

This study was carried out in 2017 at the Research and Application vineyard of Horticulture Department of Faculty of Agriculture of Çukurova University. In the study, 3 years old Trakya ilkeren, Yalova incisi and Prima grape varieties were used. In the research, the effect of a commercial microbial fertilizer (Bio fertilizer) with a pH of 3.5 to 5.5 and containing $3.5 \times 10^{7}$ cells/mL of Chlorella vulgaris algae was tested.

Applications of microbial fertilizer were made 5 times including the first one, in the average of bud burst time (30 March), the second one, before full bloom (27 April), the third one, in the berry set period (11 May), the fourth one, when the berries were about $5 \mathrm{~mm}$ in diameter (01 June) and the fifth one in the veraison time (19 June).

In the context of applications, 1) control (no fertilizer), 2) from leaf, 3) from soil, 4) from soil plus from leaf were made in the experimented. In leaf applications, $500 \mathrm{cc} / 100 \mathrm{~L}$ water and in soil applications 2 L/da doses were applied. In control application, only water was applied to the leaves and soil at the same time.

In order to determine the effect of the application on the yield and quality characteristics, 5 clusters were taken from each application and three replicates and the yield, cluster weight, length, width and size, 100 berry weight, 100 berry volume, berry length, width and size were determined. In addition, total soluble solids (TSS), acidity, pH and maturity index were examined.

In order to determine the effects of the applications on plant nutrition, leaf samples were taken during the fall period. For each application, leaf samples from different clusters were washed twice in with tap water followed by twice washing with with pure water. Leaves were dried on coarse filter paper followed by drying at $65{ }^{\circ} \mathrm{C}$ for 72 hours. Dried leaf samples were ground by agate mill and made ready for analysis.

Macroelements N, P, K, Ca, Mg and microelements $\mathrm{Fe}, \mathrm{Zn}, \mathrm{Mn}$ contents were determined:

Nitrogen $(\mathrm{N})$ : Nitrogen in the leaf samples was determined according to the Kjeldahl method as reported by Bremner (1965).

Phosphorus (P): Total phosphorus was determined using the Shimadzu model UV 1201 spectrophotometer according to vanadomolibdophosphoric yellow colour method (Kacar, 1972).

Potassium (K): Total potassium was determined using an Eppendorf Elex 6361 fluorimeter.

Calcium $(\mathrm{Ca})$, magnesium $(\mathrm{Mg})$, iron $(\mathrm{Fe})$, zinc $(\mathrm{Zn})$ and manganese $(\mathrm{Mn})$ contents of the leaves were determined by Atomic Absorption Spectrophotometer.

Variance analysis was performed according to the split plots experimental design with three replicates using JMP statistical programmer based SAS, and least significant difference test (LSD) was used for separation of means of different treatments at 5\% significance level. While microbial fertilizer application (totally 4) was used as a sub-plot, varieties (totally 3 ) considering main plots were arranged in the blocks.

\section{Results and Discussion}

The effect of the applications on the yield and cluster properties was given in Table 1. Yalova incisi (6076 $\mathrm{g} / \mathrm{vine} ; 3038 \mathrm{~kg} / \mathrm{da}$ ) gave the highest value in terms of yield but, in Trakya ilkeren (1890 g/vine) was the lowest value. The highest cluster weight (300.1 g), cluster length $(19.19 \mathrm{~cm})$, cluster width $(11.16 \mathrm{~cm})$ and cluster size (215.0) values were obtained from Yalova incisi.

It was determined that the yield (4059 g/vine), bunch weight $(249.7 \mathrm{~g})$ and bunch width $(10.86 \mathrm{~cm})$ obtained after the application of microbial fertilizer to soil+leaf was higher than that of the other applications. It has been determined that the application of microbial fertilizer on the cluster length and cluster size was not significant.

The effect of the applications on berry properties was shown in Table 2. As it can be seen from the Table, Yalova incisi grape variety showed best results in all parameters examined about the berry characteristics; while Prima variety gave the lowest values. In terms of microbial fertilizer applications, the effects of applications on 100 berry weight, length, width and size were not statistically significant. 
Table 1

Effect of applications on yield and cluster characteristics ${ }^{(x)}$

\begin{tabular}{|c|c|c|c|c|c|}
\hline Source of Variance & $\begin{array}{c}\text { Yield } \\
\left(\text { g vine }^{-1}\right)\end{array}$ & $\begin{array}{c}\text { Cluster } \\
\text { Weight (g) }\end{array}$ & $\begin{array}{c}\text { Cluster } \\
\text { Length }(\mathrm{cm})\end{array}$ & $\begin{array}{c}\text { Cluster } \\
\text { Width }(\mathrm{cm})\end{array}$ & $\begin{array}{l}\text { Cluster } \\
\text { size }\end{array}$ \\
\hline \multicolumn{6}{|l|}{ Variety } \\
\hline Trakya ilkeren & $1890 \mathrm{c}$ & $189.0 \mathrm{~b}$ & $14.12 \mathrm{c}$ & $11.55 \mathrm{a}$ & $163.1 \mathrm{~b}$ \\
\hline Yalova incisi & $6076 \mathrm{a}$ & $300.1 \mathrm{a}$ & $19.19 \mathrm{a}$ & $11.16 \mathrm{a}$ & $215.0 \mathrm{a}$ \\
\hline Prima & $2359 \mathrm{~b}$ & $157.2 \mathrm{c}$ & $17.27 \mathrm{~b}$ & $8.53 \mathrm{~b}$ & $147.6 \mathrm{~b}$ \\
\hline$L S D 5 \%$ & 251.7 & 17,5 & 1,46 & 0.69 & 22.4 \\
\hline $\mathrm{P}$ & $<0.0001$ & $<0.0001$ & $<0.0001$ & $<0.0001$ & $<0.0001$ \\
\hline \multicolumn{6}{|l|}{ Application type } \\
\hline Control & 2946 c & $191.3 \mathrm{c}$ & 16,41 & $10.23 \mathrm{ab}$ & 167,9 \\
\hline Soil & $3305 \mathrm{~b}$ & $205.2 \mathrm{bc}$ & 17,09 & $9.99 \mathrm{~b}$ & 170,2 \\
\hline Foliar & $3457 \mathrm{~b}$ & $215.6 \mathrm{~b}$ & 17,48 & $10.56 \mathrm{ab}$ & 183,3 \\
\hline Soil+Foliar & $4059 \mathrm{a}$ & $249.7 \mathrm{a}$ & 16,47 & $10.86 \mathrm{a}$ & 179,5 \\
\hline$L S D 5 \%$ & 290.7 & 20.2 & NS & 0,8 & NS \\
\hline $\mathrm{P}$ & $<0.0001$ & $<0.0001$ & 0.5039 & 0.1481 & 0.5614 \\
\hline \multicolumn{6}{|l|}{ Interaction } \\
\hline LSD 5\% & 503.4 & 35.0 & NS & 1.38 & NS \\
\hline $\mathrm{P}$ & $<0.0001$ & $<0.0001$ & 0.0985 & 0.0131 & 0.0585 \\
\hline
\end{tabular}

${ }^{\mathrm{x}}$ Mean separation within columns by LSD multiple test at 0.05 level, NS: Nonsignificant

Table 2

Effect of applications on berry characteristics ${ }^{(\mathrm{x})}$

\begin{tabular}{|c|c|c|c|c|c|}
\hline Source of Variance & $\begin{array}{c}\text { Weight of } 100 \text { berries } \\
(\mathrm{g})\end{array}$ & $\begin{array}{l}\text { Volume of } 100 \text { berries } \\
(\mathrm{mL})\end{array}$ & $\begin{array}{l}\text { Length } \\
(\mathrm{cm})\end{array}$ & $\begin{array}{l}\text { Width } \\
(\mathrm{cm})\end{array}$ & Size \\
\hline \multicolumn{6}{|l|}{ Variety } \\
\hline Trakya ilkeren & $299.3 \mathrm{~b}$ & $280 \mathrm{~b}$ & $18.98 \mathrm{~b}$ & $15.79 b$ & $301.1 \mathrm{~b}$ \\
\hline Yalova incisi & $622.6 \mathrm{a}$ & $563 \mathrm{a}$ & $25.52 \mathrm{a}$ & $19.11 \mathrm{a}$ & $488.0 \mathrm{a}$ \\
\hline Prima & $250.7 \mathrm{c}$ & $235 \mathrm{c}$ & $16.72 \mathrm{c}$ & $15.70 \mathrm{~b}$ & $262.6 \mathrm{c}$ \\
\hline$L S D 5 \%$ & 36.4 & 42 & 1.95 & 0.54 & 34.2 \\
\hline $\mathrm{P}$ & $<0.0001$ & $<0.0001$ & $<0.0001$ & $<0.0001$ & $<0.0001$ \\
\hline \multicolumn{6}{|l|}{ Application type } \\
\hline Control & 372,4 & $353 a b$ & 19,75 & 16,8 & 337,7 \\
\hline Soil & 377,3 & $336 \mathrm{~b}$ & 19,93 & 16,67 & 342,3 \\
\hline Foliar & 400,8 & $357 \mathrm{ab}$ & 21,78 & 17,06 & 373,9 \\
\hline Soil+Foliar & 413 & $393 \mathrm{a}$ & 20,16 & 16,93 & 348,3 \\
\hline$L S D 5 \%$ & NS & 49 & NS & NS & NS \\
\hline $\mathrm{P}$ & 0.1754 & 0.1289 & 0.2499 & 0.6034 & 0.2595 \\
\hline \multicolumn{6}{|l|}{ Interaction } \\
\hline$L S D 5 \%$ & 72.81 & 84 & NS & 1.07 & 68.4 \\
\hline $\mathrm{P}$ & 0.0019 & 0.0260 & 0.1764 & 0.0009 & 0.0197 \\
\hline
\end{tabular}

${ }^{\mathrm{x}}$ Mean separation within columns by LSD multiple test at 0.05 level, NS: Nonsignificant

The effect of fertilizer application on berry volume was found to be significant and the highest value was obtained from soil+leaf $(393 \mathrm{~mL})$ application. It was determined that Trakya ilkeren and Prima entered into medium berry group in terms of berry weight and volume, while Yalova incisi was introduced into large berry group (Çelik, 2011).

When the effect of microbial fertilizer on thevarieties was examined, the highest TSS (17.75\%) was found in Trakya ilkeren; however, the highest acidity value was determined in Trakya $(0.406 \mathrm{~g} / 100 \mathrm{~mL})$ and Prima $(0.404 \mathrm{~g} / 100 \mathrm{~mL})$ varieties which entered the same statistical group. The effect of $\mathrm{pH}$ on the application was not significant (Table 3). The highest maturity index value was obtained from a variety of Yalova incisi (60.21). The effect of application type of micro- bial fertilizer on acidity, $\mathrm{pH}$ and maturity were not significant (Table 3).

The effect of the applications on the macro and micro element content of the leaf samples taken during the veraison was presented in Table 4.

The effect of varieties and microbial fertilizer application on the $\mathrm{N}$ content of the leaves was not significant. In terms of $\mathrm{P}$ content, the difference was found to be insignificant in terms of the way it was applied in the level of varieties. Considering $\mathrm{K}, \mathrm{Ca}$ and $\mathrm{Mg}$ contents of the leaves, the differences between varieties and the effect of the application of bio fertilizer were statistically significant. The highest $\mathrm{P}, \mathrm{Ca}$ and $\mathrm{Mg}$ were determined in Yalova incisi variety, while highest $\mathrm{K}$ was obtained in Trakya ilkeren. The highest K, Ca and $\mathrm{Mg}$ contents were obtained from leaf applications. 
Varietal effect on micro element content was not significant in $\mathrm{Mn}$, but it was found to be important in $\mathrm{Fe}$ and $\mathrm{Zn}$ contents. The highest Fe content from Yalova incisi and Prima; $\mathrm{Zn}$ content from Prima variety were

Table 3

Effect of applications on must characteristics ${ }^{(\mathrm{x})}$

\begin{tabular}{|c|c|c|c|c|}
\hline Source of Variance & $\begin{array}{l}\text { TSS } \\
(\%) \\
\end{array}$ & $\begin{array}{c}\text { Acidity } \\
\left(\mathrm{g} 100 \mathrm{~mL}^{-1}\right)\end{array}$ & $\mathrm{pH}$ & Maturity index \\
\hline \multicolumn{5}{|l|}{ Variety } \\
\hline Trakya ilkeren & $17.75 \mathrm{a}$ & $0.406 \mathrm{a}$ & 3,77 & $44.22 \mathrm{~b}$ \\
\hline Yalova incisi & $14.91 \mathrm{c}$ & $0.249 \mathrm{~b}$ & 3,82 & $60.21 \mathrm{a}$ \\
\hline Prima & $16.44 \mathrm{~b}$ & $0.404 \mathrm{a}$ & 3,75 & $41.30 \mathrm{~b}$ \\
\hline$L S D 5 \%$ & 0.71 & 0.03 & NS & 3.41 \\
\hline $\mathrm{P}$ & $<0.0001$ & $<0.0001$ & 0.1438 & $<0.0001$ \\
\hline \multicolumn{5}{|l|}{ Application type } \\
\hline Control & 15,87 & $0.339 \mathrm{~b}$ & $3.74 \mathrm{~b}$ & $47.52 \mathrm{~b}$ \\
\hline Soil & 16,62 & $0.336 \mathrm{~b}$ & $3.82 \mathrm{a}$ & $51.73 \mathrm{a}$ \\
\hline Foliar & 16,59 & $0.378 \mathrm{a}$ & $3.76 \mathrm{ab}$ & $47.45 \mathrm{~b}$ \\
\hline Soil+Foliar & 16,38 & $0.358 \mathrm{ab}$ & $3.78 \mathrm{ab}$ & $47.60 \mathrm{~b}$ \\
\hline$L S D 5 \%$ & NS & 0.03 & 0.07 & 3.93 \\
\hline $\mathrm{P}$ & 0.2230 & 0.0273 & 0.2241 & 0.0897 \\
\hline \multicolumn{5}{|l|}{ Interaction } \\
\hline LSD 5\% & 1,41 & 0,05 & 0,13 & 6,81 \\
\hline $\mathrm{P}$ & 0,0043 & 0,0063 & 0,0001 & 0,0003 \\
\hline
\end{tabular}

${ }^{\mathrm{x}}$ Mean separation within columns by LSD multiple test at 0.05 level, NS: Nonsignificant

As a result of evaluation of the varieties and fertilizer application types, there were differences in terms of limit values (Jones et al., 1991) (Table 4), the content of $\mathrm{P}$ and $\mathrm{K}$ were deficient; $\mathrm{N}, \mathrm{P}, \mathrm{Ca}$ and $\mathrm{Mg}$ values were found to be within the limit values of sufficient and excessive. Nitrogen in Prima and $\mathrm{Ca}$ and $\mathrm{Mg}$ in Yalova incisi variety was determined as sufficient. It

Table 4

Effect of applications on macro and micro element contents of leaves ${ }^{(\mathrm{x})}$

\begin{tabular}{|c|c|c|c|c|c|c|c|c|}
\hline \multirow{2}{*}{ Source of Variance } & \multicolumn{5}{|c|}{ Macro elements (\%) } & \multicolumn{3}{|c|}{ Micro elements (ppm) } \\
\hline & $\mathrm{N}$ & $\mathrm{P}$ & $\mathrm{K}$ & $\mathrm{Ca}$ & $\mathrm{Mg}$ & $\mathrm{Fe}$ & $\mathrm{Mn}$ & $\mathrm{Zn}$ \\
\hline \multicolumn{9}{|l|}{ Variety } \\
\hline Trakya ilkeren & 2.22 & $0.20 \mathrm{~b}$ & $0.28 \mathrm{a}$ & $2.26 \mathrm{~b}$ & $0.45 \mathrm{~b}$ & $151.0 \mathrm{~b}$ & 40.6 & $31.9 \mathrm{c}$ \\
\hline Yalova incisi & 2.1 & $0.21 \mathrm{~b}$ & $0.22 \mathrm{~b}$ & $3.14 \mathrm{a}$ & $0.64 \mathrm{a}$ & $169.7 \mathrm{a}$ & 47 & $41.3 \mathrm{~b}$ \\
\hline Prima & 2.37 & $0.25 \mathrm{a}$ & $0.18 \mathrm{~b}$ & $2.16 \mathrm{~b}$ & $0.42 \mathrm{~b}$ & $176.6 \mathrm{a}$ & 38.9 & $48.6 \mathrm{a}$ \\
\hline$L S D 5 \%$ & NS & 0.02 & 0.05 & 0.52 & 0.11 & 13.3 & NS & 6.4 \\
\hline $\mathrm{P}$ & 0.2190 & 0.0002 & 0.0012 & 0.0012 & 0.0009 & 0.0018 & 0.3349 & $<0.0001$ \\
\hline \multicolumn{9}{|l|}{ Application type } \\
\hline Control & 2.24 & 0.21 & $0.22 \mathrm{~b}$ & $2.15 \mathrm{~b}$ & $0.43 \mathrm{~b}$ & $154.3 \mathrm{~b}$ & 44.3 & 41.7 \\
\hline Soil & 2.26 & 0.21 & $0.22 \mathrm{~b}$ & $2.49 \mathrm{ab}$ & $0.47 \mathrm{~b}$ & $164.6 \mathrm{ab}$ & 42.6 & 40.5 \\
\hline Foliar & 2.35 & 0.23 & $0.29 \mathrm{a}$ & $2.90 \mathrm{a}$ & $0.60 \mathrm{a}$ & $173.4 \mathrm{a}$ & 42.9 & 42.5 \\
\hline Soil+Foliar & 2.06 & 0.24 & $0.18 \mathrm{~b}$ & $2.55 \mathrm{ab}$ & $0.52 \mathrm{ab}$ & $170.7 \mathrm{a}$ & 38.9 & 37.8 \\
\hline$L S D 5 \%$ & NS & NS & 0.06 & 0.61 & 0.13 & 15.3 & NS & NS \\
\hline $\mathrm{P}$ & 0.4297 & 0.0854 & 0.006 & 0.1133 & 0.0702 & 0.0767 & 0.8614 & 0.5756 \\
\hline \multicolumn{9}{|l|}{ Interaction } \\
\hline LSD $5 \%$ & NS & NS & 0.1 & 1.05 & 0.22 & 26.6 & 23.5 & 12.8 \\
\hline $\mathrm{P}$ & 0.2032 & 0.8054 & 0.0002 & 0.0430 & 0.0256 & 0.0214 & 0.0081 & 0.0402 \\
\hline \multirow{3}{*}{$\begin{array}{l}\text { Limit } \\
\text { Values }\end{array}$} & $1.50-1.99$ & $0.22-0.29$ & $1.00-1.29$ & $1.50-1.99$ & $0.20-0.24$ & $50-59$ & $25-29$ & $18-24$ \\
\hline & $2.0-2.30$ & $0.30-0.40$ & $1.30-1.40$ & $2.0-2.5$ & $0.25-0.50$ & $60-175$ & $30-300$ & $25-100$ \\
\hline & $>2.40$ & $>0.40$ & $>1.40$ & $>2.50$ & $>0.50$ & $>175$ & $>300$ & $>100$ \\
\hline
\end{tabular}

has been determined that the values of $\mathrm{K}, \mathrm{Ca}$ and $\mathrm{Mg}$ contents in case of Biofertilizer applied by foliar application were in the excess group. It has been found that Fe was excessive in the Prima variety, but in the other two varieties, it was in sufficient amount (Jones et al., 1991). obtained. The effect of fertilizer application on $\mathrm{Mn}$ and $\mathrm{Zn}$ contents was found to be insignificant. The highest Fe content was obtained from Leaf and Soil+Leaf application.

\footnotetext{
${ }^{\mathrm{x}}$ Mean separation within columns by LSD multiple test at 0.05 level, NS: Nonsignificant
} 


\section{Conclusions}

Finally, the highest yield, bunch weight and 100 berry weight as well as other berry characteristics and maturity index values were obtained from the Yalova incisi variety.

The variety $\mathrm{x}$ fertilizer application-type interaction was significant in many properties. However, considering the overall averages, the most suitable fertilizer application was soil+leaf application for the highest yield and bunch weight. It has been observed that application from the soil causes some earlier maturation of the grapes. The contents of nutrients in the leaf samples were different in terms of varieties except $\mathrm{N}$ and $\mathrm{Mn}$. The highest $\mathrm{K}$ content was found in Trakya ilkeren; $\mathrm{Ca}, \mathrm{Mg}$ and $\mathrm{Fe}$ in Yalova incisi; $\mathrm{P}, \mathrm{Fe}$ and $\mathrm{Zn}$ were in the Prima variety. There were no significant differences in leaf $\mathrm{N}, \mathrm{P}, \mathrm{Mn}$ and $\mathrm{Zn}$ contents between fertilizer applications. For the other elements, the highest values were obtained from leaf application followed by soil plus leaf applications.

It is thought that such bio-fertilizer applications should be tested for a longer time in order to identify more significant differences between applications.

\section{References}

Abd El Moniem EA, Abd-Allah ASE (2008). Effect of Green Alga Cells Extract as Foliar Spray on Vegetative Growth, Yield and Berries Quality of Superior Grapevines. American-Eurasian Journal of Agricultural and Environmental Sciences. 4(4): 427433.

Abd El-Moniem E, Abd-Allah ASE. Ahmed MA (2008). The Combined Effect of Some Organic Manures, Mineral N Fertilizers and Algal Cells Extract on Yield and Fruit Quality of Williams Banana Plants. Am-Euras. J. Agric. \& Environ. Sci., 4 (4): 417-426.

Bileva T (2013) Influence of Green Algae Chlorella vulgaris on Infested with Xiphinema index Grape Seedlings. J Earth Sci Climate Change 4: 136-138.
Bremner JM (1965). Methods of Soil Analysis. Part 2. Chemical and Microbiological Properties, Agronomy Monograph, 9, 2.

Çelik S (2011). Bağcılık (Ampeloloji). Cilt-1. Dağıtım, Namık Kemal Üniv. Ziraat Fak. Bahçe Bitkileri Böl. Tekirdağ. Avcı Ofset, İstanbul, 428s.

Gougoulias N, Papapolymerou G, Karayannis V, Spiliotis X, Chouliaras N (2018). Effects of manure enriched with algae Chlorella vulgaris on soil chemical properties. Soil and Water Res., 13(1): 51-59.

Jones JB, Jr. Wolf B, Mills HA (1991). Plant analysis handbook. A practical sampling, preparation, analysis, and interpretation guide. pp. 213.

Kacar B (1972). Bitki ve Toprağın Kimyasal Analizleri, II. Bitki Analizleri, Ankara Üniv. Zir. Fak. Yayınları, 453s.

Mostafa RAA (2008). Effect of bio and organic nitrogen Fertilization and elemental sulphur application on growth, yield and fruit quality of flame seedless grapevines. Assiut Journal of Agricultural Sciences. 39(1): 79-96.

Özdemir S, Sukatar A, Bahar Öztekin G (2016). Production of Chlorella vulgaris and its effects on plant growth, yield and fruit quality of organic tomato grown in greenhouse as biofertilizer. Tarım Bilimleri Dergisi, 22(4): 596-605.

Safi C, Zebib B, Merah O, Pontalier P, Vaca-Garcia C (2014). Morphology, composition, production, processing and applications of Chlorella vulgaris: Areview. Renewable and Sustainable Energy Reviews. 35: 265-278.

Sönmez M, Yılmaz E (2017). The role organic/biofertilizer amendment on aggregate stability and organic carbon content in different aggregate scales. Soil and Tillage Research, 168: 118-124.

Uysal O, Uysal O, Ekinci K (2015). Evaluation of microalgae as microbial fertilizer. European Journal of Sustainable Development 4(2): 77-82. 